\title{
A Brief Discussion on the Attribution and Countermeasures of the Lack of Professional Ethics in Tour Guides
}

\author{
Xu Lei ${ }^{1, a, ~}$, Niu Miao, ${ }^{1, ~ b}$, Liu Peiwen ${ }^{2, c}$ \\ ${ }^{1}$ School of Marxism, Changchun University of Science and Technology, Changchun, China \\ ${ }^{2}$ School of Marxism, Changchun University of Science and Technology, Changchun, China \\ a18194679@qq.com, b1914431132@qq.com, ${ }^{\mathrm{c}}$ 1959213827@qq.com \\ *corresponding author
}

Keywords: Guide; professional ethics; Countermeasures

\begin{abstract}
With the rapid growth of China's economy, people's demand for tourism consumption has further increased, and tourism industry has also developed rapidly. In the tourism industry, tour guides play an important role whose professional ethics affects the service quality of the tour guides and the travel experience of tourists, and ultimately determines the development and growth of the tourism industry, even its life and death. The lack of professional ethics of tour guides in China is a hot issue to be studied. This paper analyzes the four causes of the lack of professional ethics in China's current tour guides and puts forward the maneuverability countermeasures for the construction of professional ethics in tour guides.
\end{abstract}

\section{Introduction}

In recent years, as the tourism market in China continues to heat up, the demand for guides in the tourism industry has also increased rapidly. With the rapid development of the tourism industry and the rapid growth of the number of tour guides, some dissonant factors have appeared in the tour guide team. Some tour guides do not comply with work ethics, and have low professional ethics. The phenomena of professional moral anomie such as bluff and deceive occurred occasionally. These problems have attracted wide attention from the whole society. The professional ethics of the tour guides has become a serious problem in the rapid development of the tourism industry and has become an important factor that restricts the rapid development of the tourism industry. In order to improve the overall image of the tourism industry and further release the vitality of the tourism market, it has become extremely urgent to comprehensively increase the professional ethics of the tour guides.

\section{Analysis on the causes of the lack of professional ethics of tour guides}

The current lack of professional ethics in tour guides in China is mainly due to the following four aspects:

\subsection{Professional ethics education is weak}

The weak professional ethics education of tour guides is one of the important reasons for the weak professional ethics of tour guides. On the one hand, professional ethics education has not received the attention that tourism companies should have paid. Nowadays, a considerable number of tourism companies today do not incorporate strengthening professional ethics education of tour guides into the important agenda of corporate development. There is a lack of overall planning and comprehensive arrangements for the construction of professional ethics. The education of tour guides placed emphasis on intellectual education and despised moral education; placed emphasis on business and despised politics. The training focuses on the improvement of the business level, weakens the strengthening and cultivation of professional ethics of tour guides, and lacks correct and positive value orientation. It is not conducive to the promotion of the professional ethics level 
of the tour guides. On the other hand, the current professional ethics education in the tourism industry is less effective. At present, the professional ethics education system for tour guides in China is still not perfect, and there is no regular and systematic training system. Tourism companies are lacking in professional teachers and training content.

\subsection{Lack of high quality}

The quality of the guides themselves is a subjective factor that determines the professional ethics status of tour guides. At this stage, the professional ethics status of China's tour guides can be summarized as follows:

First, there is a lack of being inured to hardships. Most of the current employees of China's tour guides are mainly young people. They grew up under the relatively superior social environment after the reform and opening up. In the process of doing business, they face all kinds of tourists and a variety of issues. It is easy to produce fears of difficulties. And they are lack of full patience and enthusiasm. They do things carelessly, and love leisure and hate labour. They do not have the responsibilities that a tour guide should have.

Second, the initiative to consciously raise the level of professional ethics is poor. Some of the tour guides have insufficient self-consciousness to strengthen their moral cultivation and enhance their professional ethics. They cannot understand the significance of strengthening their professional ethics and literacy from the perspective of their own social responsibilities and professional missions. They lack professional identity and sense of social responsibility. They are not self-requiring and have low expectations. They don't know enough about the importance of professional ethics, they can't consciously and actively learn relevant norms of professional ethics, and they have poor sense of execution in the process of employment.

\subsection{Imperfect moral construction mechanism}

In recent years, professional ethical quality of tour guides has received increasing attention in the society. The tourism administration also successively introduced some regulations and rules that govern the professional ethics of tour guides. However, in practice, it is unable to be implemented. There is a lack of specific systems and measures, a lack of effective and strict guides for salaries, rewards, punishments and supervision mechanisms.

First, the compensation system is irrational. At present, there are "three nos" personnel in China's tour guide practitioners, that is, no basic salary, no insurance benefits, and no social security. The tour guide industry is an integrated service industry with high physical fitness and intelligence. It requires a lot of physical and energy input to coordinate the various problems in the work process. However, high-intensity investment has not been guaranteed by income. This often leads to a huge psychological drop in the guides. It is easy to produce job burnout, which will directly lead to the loss of excellent tour guides.

Second, the reward and punishment mechanism is not perfect. At this stage, there are no clear standards and measures for rewards and punishments within our country's tour guide management system. The travel agency's incentive standards for tour guides are often based on the group numbers that the tour guides had and the number of attendance days. They are not directly related to the quality of tour guide services and the satisfaction of tourists with the service. And the reward is also focused on a certain amount of material reward, not linked to job titles and promotions. The form of reward is relatively simple, which can not effectively stimulate the enthusiasm of the tour guides and the sense of professional identity.

Third, the supervision is ineffective. A sound and strict supervision and management system can effectively prevent the occurrence of professional moral anomie behavior of tour guides. When tour guides encounter a behavior that violates professional ethics, it can find and guide them in a timely manner so as to avoid the bad influence caused by the misguided morality of the tour guides. At present, there are still some drawbacks and limitations in the supervision and management system of China's tour guides, which restricts the promotion of tour guides' professional ethics and the optimization of tour guide services. 


\subsection{The negative impact of the market}

The order of operation in the tourism market is still not perfect, and the new moral system that is compatible with it has not yet been fully established. The professional ethics construction of tour guides has a negative influence that can not be ignored. It is easy to induce money worship, egoism, and hedonism. It distorts the value orientation of some tour guides, obscures the ideals and beliefs, and deteriorates moral standards.

Some guides make money and wealth the ultimate goal of their own practice, and pursue the maximization of material benefits. Under the temptation of economic interests, they have abandoned the ideology of hard-working, taken a speculative psychology, and even resorted to unscrupulous profits. The viewpoint of the supremacy of interests has seriously disrupted socialist ethics and hindered the formation of good professional ethics for tour guides.

\section{Countermeasures for the construction of professional ethics of tour guides}

The four measures that are improving the professional ethics education of tour guides, giving play to the main role of professional ethics in tour guides, constructing a long-term mechanism for the development of tour guides' professional ethics, and optimizing the moral public opinion environment for the development of tour guides' professional ethics are extensively operational and feasible, which can promote China's current professional ethics of tour guides.

\subsection{Improving professional ethics education}

The practice of tour guides proves that if we want to establish professional ethics principles and norms that are compatible with the needs of the industry in the personal consciousness of the guides, and to turn them into individual special professional ethics needs, to make them form professional ethics beliefs and requirements, and to equip them with professional ethics behaviors and habits, we must give full play to tourism enterprises' professional ethics education for tour guides.

First, updating professional ethics education concept. Tourism companies must recognize the important position and effect of professional ethics in the guide's own career process and the development of company and the industry. The planning and deployment of professional ethics training for tour guides should be well done, and the cultivation of professional ethics quality should be put on a prominent position to forming a good situation in which occupational ability cultivation and professional ethics training go hand in hand.

Second, enriching the content of professional ethics education. The tourism enterprises must closely in accordance with the professional ethics of the tour guides when conducting professional ethics training for the tour guides, keep close to the guides' ideas and work practices, continuously enrich the contents of professional ethics education and enhance the effectiveness of professional ethics education.

Third, innovating the methods of professional ethics education. Changing the traditional "one-way indoctrination" education model in the past, shifting the acceptance of ethics education from passive acceptance to active absorption. Secondly, the theory and practice of ethics education are combined. Finally, the innovating work methods and enriching the propaganda carrier.

\subsection{Playing the main role on the construction of professional ethics}

Professional ethics education is a necessary condition to develop good professional ethics. While, self-cultivation is an inherent guarantee for enriching and enhancing the professional ethics of tour guides. Guides should consciously continue to learn from the social life with spiritual food, enrich and improve themselves. By learning about advanced ethics theory knowledge, they should find gaps against standards and constantly introspect their behaviors. Internalizing the external professional ethics norms into moral consciousness, strengthening self-discipline, and then translating it into guides' professional ethics code of conduct, and constantly testing and improving it in the moral practice, and gradually form good moral habits of morality, quality and character in work and life. 


\subsection{Building a long-term mechanism of professional ethics construction}

The construction of professional ethics requires the free will of moral individuals to mobilize their enthusiasm and initiative. However, if we want the cultivation of professional ethics to be effective, we must establish a scientific and feasible construction mechanism. Through the arrangement of the corresponding mechanism, the rights and obligations in the course of the guide work practice are set and configured, and the corresponding reward and penalty standards are stipulated, and their professional behaviors are strictly supervised and managed. Those who meet the requirements of professional ethics should be praised and some guides should be criticized for failing to meet the standards, making the pressure on the tour guide to be involuntary. This will result in an overall positive and cooperative force that achieves the goal of behavior orientation and enhances the professional ethics level of the tour guides.

From the perspective of the tourism industry, the tourism industry should strengthen external supervision, regulate the order of the tourism market, and optimize the working environment of the tour guides. We should promote the integrated construction of administrative, tourist enterprises and public opinion supervision, strengthen internal supervision and strictly restrict the professional behavior of tour guides. From the perspective of travel agencies, travel agencies must use professional ethics as a key element in their selection and employment. The tour guide is a staff member of a travel agency. The supervision of the travel agency has an important influence on the professional ethics of the tour guides. In turn, the professional ethics of the tour guide also determines the survival of the travel agency. In the new situation, we should also innovate the supervision of the network media. Through the open and transparent network information, the guide's behavior can be truly exposed in the light of the social environment. We should use the powerful public opinion to make the guides consciously abide by professional ethics and serve the tourists wholeheartedly.

\subsection{Optimizing the good social environment of the construction of professional ethics}

First, creating a good atmosphere of public opinion. As the main position of the public opinion, the mass media should actively create a leading value orientation, guide the guide's value orientation and mass opinion guidance correctly. The media should shoulder their own social responsibilities, further increase the public's overall and objective understanding of the entire group of guides, clarify ambiguous concepts, and conduct publicity and reporting on individual guides and groups that have outstanding performance and strictly abide by professional ethics. Make more positive publicity, set up advanced examples and promote positive attitude, reshape the image and style of the tour guides, enhance the sense of professional honor of tour guides, increase the enthusiasm and confidence of the tour guides, and inject strong power for the guides to cultivate their own professional ethics and ethos.

Second, establishing socialist core values and lead a good social atmosphere. It is an important external condition to guide the social atmosphere and create a harmonious social atmosphere with the socialist core values.

The professional ethics of tour guides not only relates to the development of the professional career of the tour guide, but also relates to the future direction of the tourism industry in China and even the national image. It is of great theoretical and practical significance to improve the professional moral level of the guide.

\section{References}

[1] An Shenjian. Problems and Countermeasures in the Professional Ethics Construction of University Teachers at Present[J]. Education Exploration,2009(1).

[2] Sun Yu. Problems and Countermeasures in the Professional Ethics Construction of Tour Guides in China in the New Period[D]. Master's thesis of Jilin Agricultural University,2013(6).

[3] Wu Xiaoyi. The Dimension and Influencing Factors of Professional Moral Behavior of Tour 
Guides[J]. Tourism Science, 2012(6).

[4] Yu Jie. Study on the present situation and Countermeasures of guide professional ethics[D]. Master's thesis of Mudanjiang Normal University, 2012.

[5] Shi Wei. Study on Professional Ethics Construction of Tour Guides[D]. Master's thesis of Shanxi University of Finance and Economics, 2013(3). 